Portland State University

PDXScholar

\title{
The Fourth Avenue Street Seat: an Exercise in Disbanded Bureaucracy
}

Rhiannon Reynolds

Follow this and additional works at: https://pdxscholar.library.pdx.edu/honorstheses Let us know how access to this document benefits you.

\section{Recommended Citation}

Reynolds, Rhiannon, "The Fourth Avenue Street Seat: an Exercise in Disbanded Bureaucracy" (2018). University Honors Theses. Paper 532.

https://doi.org/10.15760/honors.537

This Thesis is brought to you for free and open access. It has been accepted for inclusion in University Honors Theses by an authorized administrator of PDXScholar. Please contact us if we can make this document more accessible: pdxscholar@pdx.edu. 
The Fourth Avenue Street Seat: An Exercise in Disbanded Bureaucracy

by

\title{
Rhiannon Reynolds
}

An undergraduate honors thesis submitted in partial fulfillment of the requirements for the degree of

\author{
Bachelor of Arts
}

in

University Honors

and

Architecture

Thesis Adviser

Todd Ferry

Portland State University 


\begin{abstract}
The Fourth Avenue street seat on the campus of Portland State University was opened to the public in the summer of 2015. It was originally designed and constructed by students from Portland State's Architecture department from 2013-2014, and was funded and constructed with significant help from local groups, mainly the former Institute of Sustainable Solutions (ISS) and the South of Market Eco District (SOMA), both now disbanded. Since opening, the parklet has suffered concerns with maintenance and a lack of ownership from the groups previously involved. This paper follows the author's attempts to understand the status of the street seat in late 2017 and its context at the scale of contemporary urban design, as well as chronocoling her process of renovating and re-permitting the street seat.
\end{abstract}

\title{
A Post-Occupancy Study on the Fourth Avenue Street Seat
}

The idea of conducting a post occupancy study was inspired by Kalina Van Derpoel's thesis; The Role of Healing Gardens. In her thesis, Van Derpoel spent conducted a post-occupancy study of healing garden in a children's hospital in Portland, Oregon. Each section of the healing garden was designed with specific use (children's play, contemplative and private spaces, spaces to stroll, gathering spaces). However, through her observations, she concluded that only a fraction of the spaces were used in the way that they were designed, and many of them were hardly used at all. Her thesis demonstrated a post-occupancy study that could provide valuable feedback to designers.

In wanting to conduct my own post-occupancy study, I was advised by Van Derpoel to choose a small space in which one observer could realistically note every user's coming and going, and duration of stay. Todd Ferry of Portland State's Center for Public Interest Design suggested the 4th Avenue street seat due to its connection with the university its proximity on campus. Doing a post-occupancy study of the street seat would be a good study of the effects and success of a piece of a Street Seat. These observations would be coupled with a critical analysis this work of tactical urbanism.

\section{What is Tactical Urbanism, and Does the Street Seat Qualify?}

Tactical urbanism defines a type of construction or installation, usually temporarily installed and often created from community support and by bottom-up means of organization rather than through formal methods. Acts of tactical urbanism can happen quickly when they are executed by neighborhood organizations and artists' collectives rather than by bureaucratic groups. Kathleen Corey, in her Master's Thesis Making Space: an Exploration of street seat in North America and Vancouver, describes tactical urbanism as "A term popular [to those] seeking to add vitality to unused or underutilized land" ... "commonly described as 'urban interventions', these new public spaces are often executed as quick, low cost projects open for anyone to experience" (p. 7). 
Tactical urbanism has several motives, one of which is community engagement. Communities use this tactic to take over and re-imagine spaces in a way that could serve the community better. In setting up a pop-up, the community demonstrates what they would like to see in a space. When successful, the attention can lead to increased support, both informal and formal, of the project. In testing out an idea without permanence, tactical urbanism can act as a "trial run" for a new use of an underutilized space. If the project is successful, it can be the evidence in support of larger, more permanent changes to the urban landscape structures requiring more funding.

These are four characteristics of tactical urbanism that I will use in looking at street seat.

tactical urbanism:

1. Creates precedent for/ provokes larger changes

2. Stems from bottom-up, community driven projects

3. Creates spaces that are open to all

4. Is usually temporary

The 4th Ave. street seat was hardly executed quickly or on a low budget, and it was not meant to be temporary. The planning and construction took 18 months and its construction cost $\$ 15,000$. The materials used were meant to be sturdy (using Juniper lumber instead of pine, for example, and sturdy bent steel planters) and resistant to weathering. The permit issued to the street seat was for two years, however the materials used and their expense indicated a desire that the project last longer. ${ }^{1}$

In engaging the community, the 4th Avenue street seat was and wasn't successful, and the efforts were hardly bottom-up. The conception of the street seat originated from a studio class at Portland State's Architecture Department taught by B.D. Wortham Galvin in the winter term of 2013. The class proposed several different designs for a local street seat. After the studio's completion, students and Wortham Galvin worked towards the permitting, construction and funding of the chosen design from the studio.

From January 2013- June 2015, many parties organized and contributed to the funding and construction of this seating area. The city was engaged in the entire process and was happy to endorse Portland's first Public street seat. The leading organization was Portland's South of Market Eco District (SOMA), an organization that helped gain funding for the project and formally support the project. The Fourth Avenue street seat's formal name is the SOMA street seat, as listed on the city permits. However, after the street seat's construction, SOMA disbanded, leaving the street seat without formal ownership or a maintenance coordinator.

However, the street seat project failed to engage an essential community- the owners and employees of the food carts for which the street seat was built. While the food carts did donate

\footnotetext{
${ }^{1}$ Information gained from a meeting with Michael Coon, November 2017.
} 
their tips for a period of time to help fund the construction, the food cart owners/ employees were not further engaged. Had they been more engaged, perhaps they could have avoided the street seat falling into disrepair about a year after its construction.

The Fourth Avenue street seat both sets a precedent, and follows one. While potentially acting as a precedent for future public street seat, Portland hasn't necessarily seen more projects that explicitly follow the example of the Fourth Avenue street seat. Two additional public street seats can now be found in Portland, however they came from a design-build competition hosted and funded by the Portland branch of the American Institute of Architecture.

\section{PARK(ing) Day}

The phenomenon of taking over parking spaces and turning them into public space has been institutionalized through "PARK(ing) day", an annual event late September. "This annual global event brings together community members, often artists, designers and activist, who collectively convert parking spaces into temporary public parks". [Citation-Corey Kathleen] PARK(ing) day originated in 2005 when a design studio in LA, Rebar Group, playfully converted a parking space into a park using sod, a bench and a potted tree. Since then, the day has been successful worldwide, and created a precedent of parking-space interventions which the 4th Avenue street seat followed.

At the same time as the Fourth Avenue street seat was being designed and was seeking funding, the Portland American Institute for Architecture was promoting a design-build challenge for two public street seats.

On September 20, 2014 AIA Portland's Center for Architecture's Street Seat Competition announced their winners. Two designs were built and displayed in front of AIA Portland for several weeks following. The street seats were later adopted by the Alberta Main Street Neighborhood association and reinstalled as "public" street seat on Alberta street in front of businesses Tin Shed and Vita Cafe. The businesses are currently responsible for maintenance and insurance, however, it is posted that anybody is allowed to occupy the seat, not only restaurant patrons. 


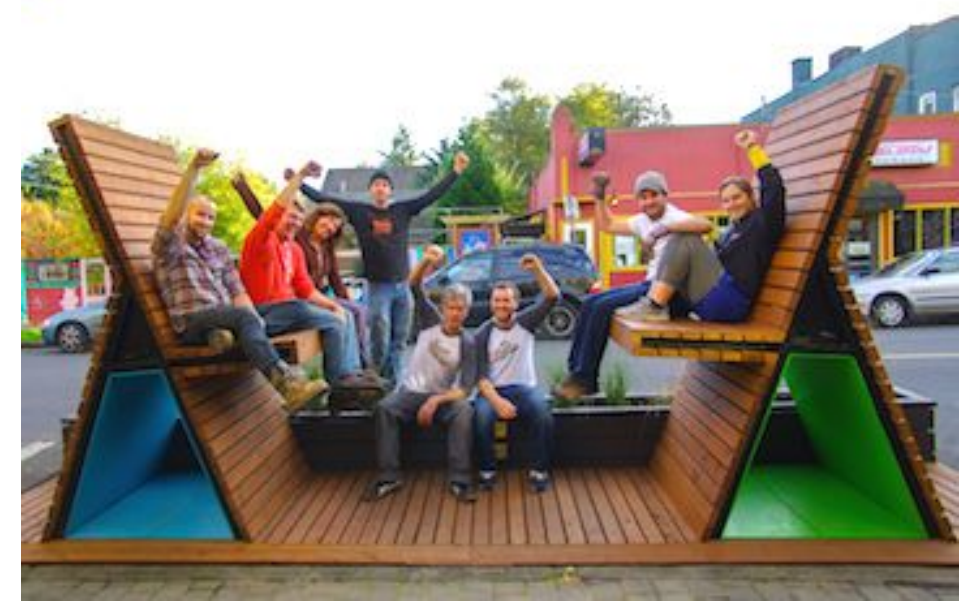

"A Dialogue" was a winner of the 2014 AIA street seats competition. It is currently installed in front of a cafe on Alberta St. Image credit: Scott Edwards Architecture.

\section{Observations of the Street Seat}

Initiating a post-occupancy study, during the first two weeks of October 2017, I spent 7 lunch hours observing the street seat on Fourth Avenue. My findings are as follows: on the sunny and partially cloudy days that I observed, an average of 35 people/ hour used the street seat. On rainy days, that number fell to 8 people/hour using the street seat- and those who used it stayed for a much shorter duration. These were my findings for the lunch hour when school was in session. On weekends and in the hours that the food carts were closed (the majority after 3 or 4 $\mathrm{pm}$ ), the street seat went nearly completely unused. I did not do any observations during the summer. 


\section{FOURTH AVENUE PUBLIC PARKLET}

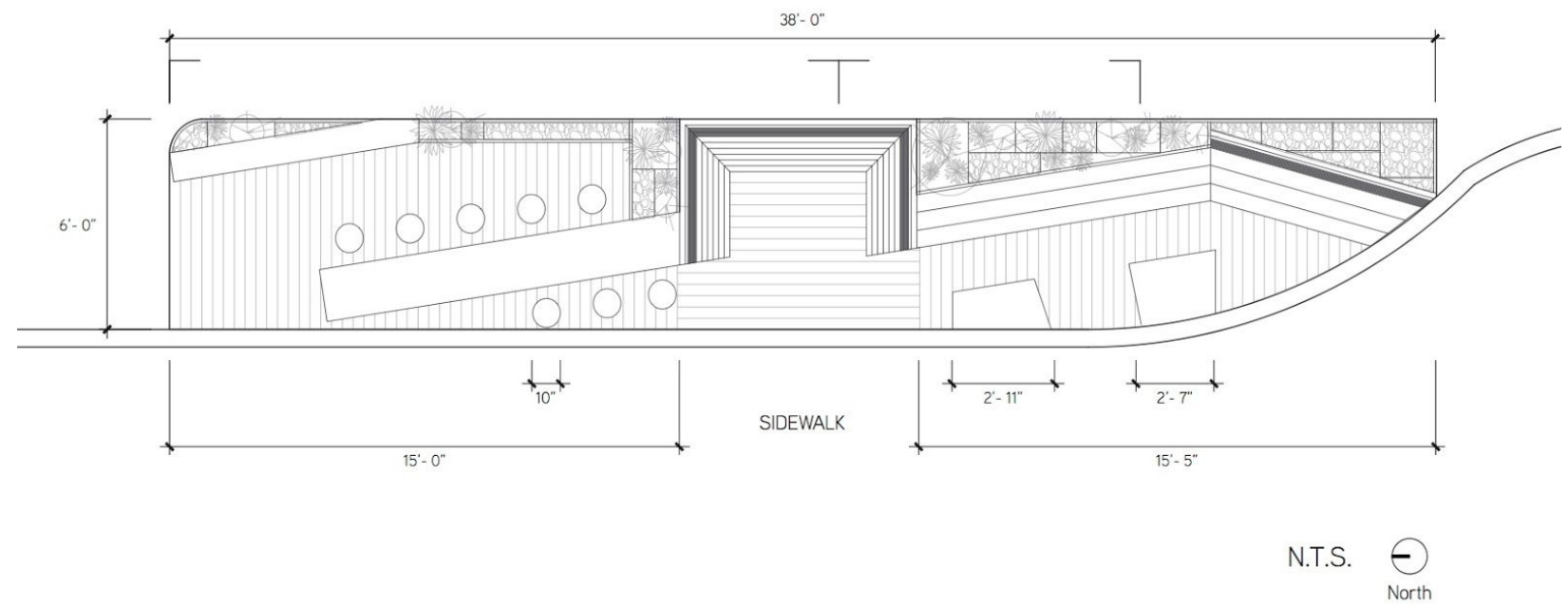

Plan of the Fourth Avenue Parklet as listed on the permit. Image credit: Michael Coon and Portland Bureau of Transportation.

The street seat was being used in a predictable way. Diners took the opportunity to sit with their food when the weather was nice and the food carts were open, and the street seat was used much less when it was raining and/or the food carts were closed. Many people also used the street seat as a prop to lean against or stand by while waiting for their food.

When I spoke to the food cart employees and owners, many of them expressed a wish that the street seat have a awning. The street seat was originally designed to have an awning. However, designing the awning to resist wind uplift was too much of a challenge for a site where alterations of the asphalt below were not allowed, and the awning design was abandoned. For this reason, and for reasons of cost, none of the street seat in Portland have awnings, although they would all likely benefit from them.

However, I soon abandoned my original goal of post-occupancy study by observation, as it became clear to me that this was not attention that the street seat needed. The street seat had fallen into total disrepair. Lack of maintenance had left all the materials in a state of decay. More than that, food trash accumulated daily on the street seat, which was an attraction for birds, who then further spoiled the space. 


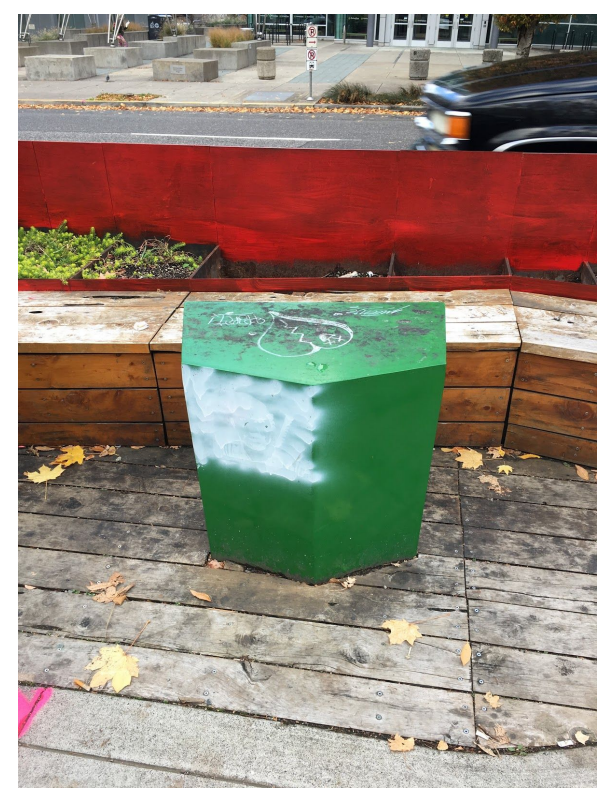

The condition of the street seat, September 2017. Photo credit: Rhiannon Reynolds

\section{Moving Towards Renovation}

I began to investigate the state of the street seat. Firstly, I was put in contact with Michael Coon. Currently employed at GBD Architects, Michael was a graduate student at Portland State University who partially led the charge on the street seat design/ build. He had such a passion for the project that he saw it through to its completion even months after his graduation. Michael was a valuable resource in understanding the design intent of the street seat, and the process of its construction. We were both motivated to try and restore the street seat to a better state.

The original permit document provided clues as to why the maintenance had been neglected:

"The SoMa Project Coordinator will visit the Street Seat once a week. During this visit the street seat will be swept, trash picked up as necessary, and the structure will be inspected for any other maintenance including below platform cleaning. Based on the needs during this weekly visit, more frequent cleanings may take place if necessary, especially in rainy months to check below the platform. Additionally, the parking lot/food cart property owners hire someone to sweep the lot once a week and pick-up trash daily, thus this person will help keep an eye on the cleaning of the SoMa Street Seat."

Despite good intentions to maintain the space, ultimately SoMa disbanded, its Project Coordinator was relieved of her responsibility, and the parking lot/ food cart owners did not hire somebody to clean the Street Seat.

Being a public project, the creation of the street seat was extremely bureaucratic, complex and lengthy. The permit itself includes 5 letters from parties in formal support of the project. The property owner, the Institute for Sustainable Solutions, the City of Portland Bureau for Planning and Sustainability, the South of Market Ecodistrict and the Portland Downtown Neighborhood Association. The project relied on 1,650 volunteer hours over the course of eighteen months. ${ }^{2}$

${ }^{2}$ PDXMonthly.com 
The construction of private street seat in Portland is considerably different than the Fourth Avenue project. Those wishing to construct seats in front of a bar or restaurant focus on cost-to-seat ratio (with several exemplary street seat also paying attention to design). Private street seat are constructed much more quickly. For example, Oven and Shaker restaurant in the Pearl District installs its street seat every summer and dismantles it every fall- the best way to maximize exterior seating when the weather is nice and avoiding dues to the city for lost parking revenue in the winter.

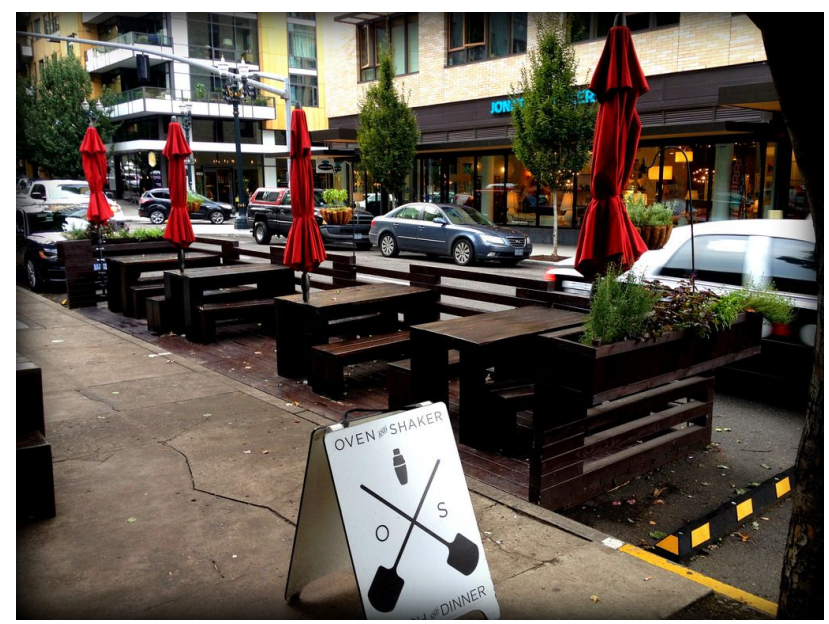

Oven and Shaker's Street Seat is a good example of a private (restaurant) street seat to seasonally increase seat numbers (and profit). Photo credit: Oven and Shaker.

Fundraising for the street seat on Fourth Avenue happened in a variety of ways. SOMA was able to acquire approximately $\$ 500$ in donations, and a crowdfunding page through the Portland State Foundation raised the bulk of the $\$ 15,500$ for the project.

At the point that I spoke with Michael, in November 2017. the permit had been about 6 months expired.

I met with Sarah Figliozzi, head of the Portland's Bureau of Transportation (PBOT)'s street seats program, to ask her about the potential of re-permitting so that the street seat could be renovated and not demolished. My interest in the street seat was timed well; the city and previous members of SOMA had began to debate the fate of the street seat, including discussions on who could take over its maintenance and if it should be removed. The Street seat program would be willing to re-permit the document, given a few conditions. Firstly, some solution had to be found to the daily cleaning and maintenance. ${ }^{3}$

The task of a one-time renovation, cleanup and replanting of the street seat was the subsequent task that I took on. With the help of Jennifer Mcnamara, I located about $\$ 600$ in funds left over in the defunct SOMA Eco District's accounts set aside for this purpose.

\footnotetext{
${ }^{3}$ Meeting with Sarah Figliozzi, November 15, 2017.
} 
The problem of continued maintenance, past my intervention being the reason I felt compelled to help the street seat in the first place, became difficult. Sarah suggested that the best way to ensure maintenance of the street seat was to work with the adjacent food cart owners and get their formal agreement of cleaning the street seat. The street seat being very expensive to construct and providing a serious advantage to the carts adjacent provided the owners and employees with an incentive to not want to see the street seat torn out.

While securing a formal agreement from the food cart owners would hopefully keep the street seat clean on a daily basis, what would happen to the street seat in a year's time, or two years, when it once again was in need of a renovation and a new permit?

It had been made clear to me by several parties that, while the architecture department had designed and helped build the street seat, Portland State University was not willing to take on ownership or maintenance of the street seat. The city, additionally, could issue the permit but only if there was a party able to pay the re-permitting fee. For all intents and purposes, SOMA owned the street seat, but had disbanded since its construction. It seemed to me that the street seat was essentially owner-less. In all my discussions with all the parties involved in its conception, people were extremely helpful in the goal of renovation and cleanup, however nobody was willing, or found themselves in a position, to take ownership of the street seat.

The maintenance issues associated with this street seat raise questions about street seat and tactical urbanism. In which cases should tactical urbanism be temporary? Who can, and should, take ownership of projects like this? Can material choice make a difference on how often maintenance is needed?

\section{Renovation}

After securing a daily maintenance agreement from 5 adjacent food carts, the task of cleanup began. On February 17 and March , 6 of my classmates and Nathan Hamilton (a previous member of SOMA) gathered to clean up and renovate the parklet. New plants were generously donated to the project by the Portland Nursery. We cleaned the parklet of trash, dead leaves and dirt and removed the graffiti (at the expense of ruining the powder coated tables). We also rebuilt and replaced a wooden table and stools. Ultimately, the parklet did not return to a like-new condition but the experience of seating and eating at it was improved.

\section{Sustainability}

In the case of the 4th avenue street seat, sustainability was on the word on everybody's mind when making this space. Public support, and the support of SOMA and ISS, hinged on this being a sustainable project.

On a metric of triple bottom line (social, environmental and economic) sustainability, I would argue that the parklet satisfies some qualifications and not others. Socially, this project 
succeeds in placemaking with a minimal footprint. It provides social opportunities to sit and socialize where there previously were none.

Material choice provides clues to the seats' environmental impact. Juniper was chosen as the wood for its longevity and low-VOC finish was used on the wood. Reused materials include only reused escalator handrails, which clad one of the interior partitions and are arranged as a pattern on the street-facing steel. The handrail details are decorative and interesting, but not essential to the design. Portland State's Institute for Sustainable Solutions (ISS) and the South of Market Eco District (SOMA) were integral in the project. As their names would suggest, they offered their support of this project because it was always considered an eco-friendly or sustainable construction.

This project used $\$ 15,000$ of new material resources, however it did succeed in replacing a parking space with some permeable planting space. The street seat's planters function as small bioswales, however I would argue that their impact on reducing runoff is negligible because the planters don't cover more than 15 square feet. Additionally, there are few surviving plants to sequester rainwater that enters the planters, which means that the majority of rainfall ultimately drains through the dirt to the street.

While the actual impact of the street seat on preventing materials from ending up in the landfill (in the case of the escalator handrails), and reducing stormwater runoff may be small, perhaps the real "sustainable" value of the project is its reflection in a change of attitude about paved surfaces. It also reflects an attitude that prioritizes pedestrian over automobile traffic. For this reason, I would argue that the value of the street seat is experiential and ideological, rather than quantifiably sustainable.

\section{Takeaways and Implications}

The street seat is valuable to Portland because it demonstrates that the city is willing to formally support this type of project. The Street seat program falls within the Liveable Streets Vision set by the city in 2016. In their 2017 Livable Streets Strategy, the city's vision states, "PBOT supports Community Placemaking on Portland Streets". The Bureau of Transportation's encouragement of livable streets reflects a trend in urban design towards walkable, approachable streets. This movement comes in the backlash of large highway and parking lot construction from car-centered design of the $50 \mathrm{~s}-90 \mathrm{~s}$.

While demonstrating that a public street seat like this is possible in Portland, the Fourth Avenue street seat relied heavily on several motivated individuals, primarily Michael Coon and BD Wortham Galvin, who were willing and able to work on the project for over a year. The personal perseverance needed and navigating the complex methods in which they sought funding could seem intimidating to others wishing to follow in the street seat's footsteps. For example, it took me several months to begin to understand how this project happened. Even after studying this 
street seat over the course of two terms, some details of the design and funding remain unclear to me.

For this reason, I began working at the beginning of 2018 In working alongside Sarah Figliozzi at PBOT, to craft a precedent guide to those looking to build a street seat. This case study guide, attached, contains specific information about the construction and design of some of the more successful street seat in Portland (upon Sarah's suggestion). Creating an open-source guidebook is an attempt for businesses and parties looking to design street seat to learn from the successes and failures of others. The case study guide (which is to ultimately be published on PBOT's street seat website) provides a realistic understanding of cost of construction, a materials palette, and a list of potential designers and builders for hire.

Some takeaways from the Fourth Avenue project were that less time could have been spent on securing access to expensive materials and more could have been spent on trying to create a maintenance plan for the seat. The city encourages vibrant designs of street seat and they expect a maintenance plan/ supervisor listed on the permit. I might suggest, after my experience with the Fourth Avenue street seat, that the latter is more important.

After spending time with this small construction and those passionate (and apathetic) about it, I left the street seat with some rhetorical questions about the motivation behind its construction. Who benefits most from this public installation? The public, having a place to eat their food cart meals? The food carts adjacent, who potentially receive more business, and have happier customers? The city for demonstrating its support of placemaking projects? Individuals like Michael Coon and BD Wortham-Galvin who gained experience in construction and project management? Myself, for being able to take over the project to fulfill my thesis? After spending time with this small construction and those passionate (and apathetic) about it,

\section{Sources}

Birdsall, M. (2013). Parklets: Providing space for people to park. . themselves. Institute of Transportation Engineers. ITE Journal, 83(5), 36-39. 
Blank, S., Dodson, E., Farnen, H., Harrasser, S., Kido, J., \& Sanguinetti, M. (2004). City Repair, The Urban Plaza, and Public Spaces. Portland, OR.

Brozen, M., Loukaitou-Sideris, A. (2012). Reclaiming Right-of-Way - Best Practices for Designing and Implementing Parklets. Los Angeles: UCLA Luskin School or Urban Affairs.

Corey, K. (2014). Making Space: An Exploration of Parklets in North America and Vancouver. Ontario, Canada: University of Guelph.

Duany, A., Plater-Zyberk, E. \& Speck, J. (2001). Suburban Nation: The Rise of Sprawl and the Decline of the American Dream. New York: North Point Press.

Francis, Mark. (2003). Urban Open Space: Designing for User Needs. Washington D.C. : Island Press.

Gehl, J. (2010). Cities for People. Washington D.C.: Island Press.

Gehl, J. (2013). How to Study Public Life. Washington D.C.: Island Press.

Jacobs, J. (1961). Death and Life of Great American Cities. New York: Random House.

Johnston, K. (2012). Public Space and Urban Life: A Spatial Ethnography of a Portland Plaza. Thesis (M.U.S.): Portland State University.

Krier, L. (2009). The Architecture of Community. Washington, Covelo, London: Island Press.

Koue, C. (2013). Sustainable Implementation of Emerging Infrastructure in Cities: A Case Study of Parklets. Washington DC: Georgetown University.

Mehta, V. (2008). Walkable Streets: Pedestrian Behavior, Perceptions and Attitudes. Journal of Urbanism: International Research on Placemaking and Urban Sustainability.

Ocubillo, R. A. (2012). Experimenting with the margin parklets and plazas as catalysts in community and government (Order No. 1529044). Available from ProQuest

Dissertations \& Theses Global.

Orloff, C. (2004). If Zealously Promoted by All: The Push and Pull of Portland Parks History. The Portland Edge: Challenges and Successes in Growing Communities (p.321). Washington D.C.: Island Press. 
Panganiban, J. (2014). Citywide Assessments of Parklets \& Plaza. San Francisco Planning Department.

Smead, L. (2013). Parklets in Somerville: A resource for implementation (Order No. 1552998). Available from ProQuest Dissertations \& Theses Global.

Smith, E. E. (2016). An exploratory assessment of parklet usage in seattle: Methods and findings (Order No. 10138692). Available from ProQuest Dissertations \& Theses Global.

Smithsimon, G. (2008). Dispersing the Crowd: Bonus Plazas and the Creation of Public Space. Urban Affairs Review, 43(3), 325-351.

Sandstrom, R. (2015). This New Mini-Park at Portland State is Completely Adorable in Every Way.

https://www.pdxmonthly.com/articles/2015/7/20/this-new-mini-park-at-portland-state-is-complet ely-adorable-in-every-way

Vander Poel, K. (2015). "The Role of Healing Gardens". Student Research Symposium. http://pdxscholar.library.pdx.edu/studentsymposium/2015/Posters/4

Whyte, W.H. (1980). The Social Life of Small Urban Spaces. Washington D.C.: The Conservation Foundation.

Whyte, W.H. (1990). City: Rediscovering the Center (p.386). New York: Anchor Books.

Portland Bureau of Transportation (2017). Livable Streets Strategy

https://www.portlandoregon.gov/transportation/article/667260 


\section{Public Street Seat: 4th Avenue}

THE STORY: Portland's first Public Parklet was designed and built over a period of 18 months from 2013-2015. Parties involved include the South of Market Eco District (SOMA), Portland State Architecture department, City of Portland Street Seats and Portland State University Institute for sustainable solutions (ISS)

\section{ABOUT ME}

Location: Corner of SW 4th Ave and College St.

Date Opened: June 1, 2015

\section{Cost of Construction: $\$ 15,000$}

Permitting Cost: $\$ 600 /$ initial permit. $\$ 250 /$ permit renewal. No additional charges for this public street seat.

\section{Number of Seats: Up to 12}

Designed By: Portland State University's School of Architecture

Built By: Green Hammer Construction and Portland State University Architecture students

\section{LESSONS LEARNED}

- Maintenace Strategy is Key two parties were listed as being responsible for maintenance- the South of Market Ecodistrict (SOMA)and the adjacent food cart owners. Because SOMA disbanded and the food cart owners failed to maintain the space, this parklet fell into disrepair after a year of use and exposure to the elements.

- Designing an Awning is Challenging an awning would greatly benefit this parklet -while designed originally with an awning, engineering one to resist uplift proved too difficult and costly

- Creative Funding is Possible two groups, Portland State's Institute for Sustainable Solutions and SOMA, helped raise funds. The parklet recieved material and plant donations, but crowdfunding attempts were mostly unsucessful. This costly but beautiful public space was built without private funding.

\section{MATERIALS USED}

\section{Folded Steel Plates}

Form the Planters

\section{Juniper Lumber}

Was chosen as the primary material for this parklet due to its durability

\section{Escalator Handrail}

Recycled rubber handrails were used as details on the interior and as a protective buffer on the street side

\section{Landscaping}

Folded steel planters currently hold Orange Sedge, Aztec Pearl and Sedum plants, chosen to be hearty and require minimal maintenance
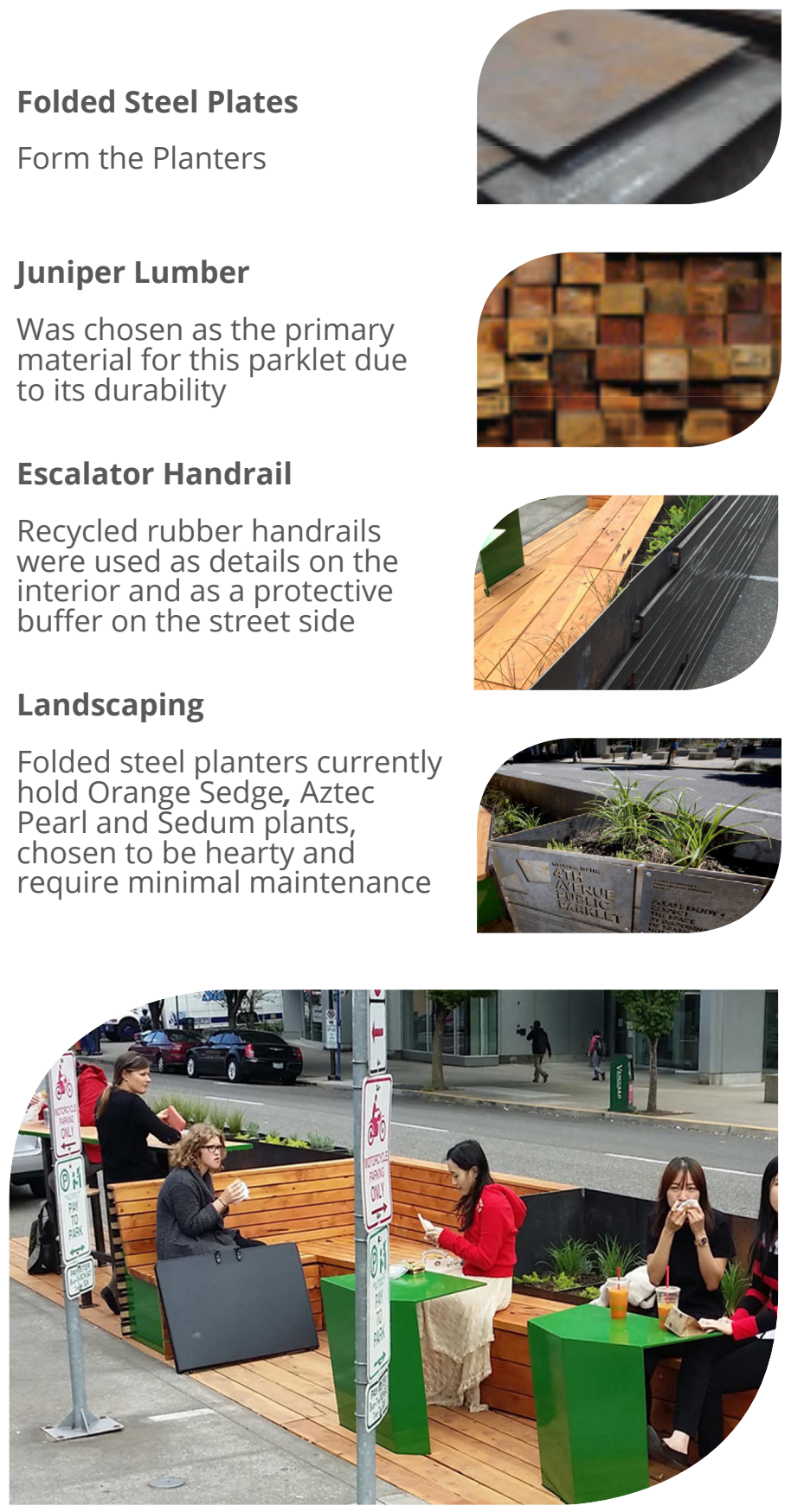

Photo Credits: Michael Coon 


\title{
Permit Drawings
}

\author{
SITE CONTEXT AND DIMENSIONS
}

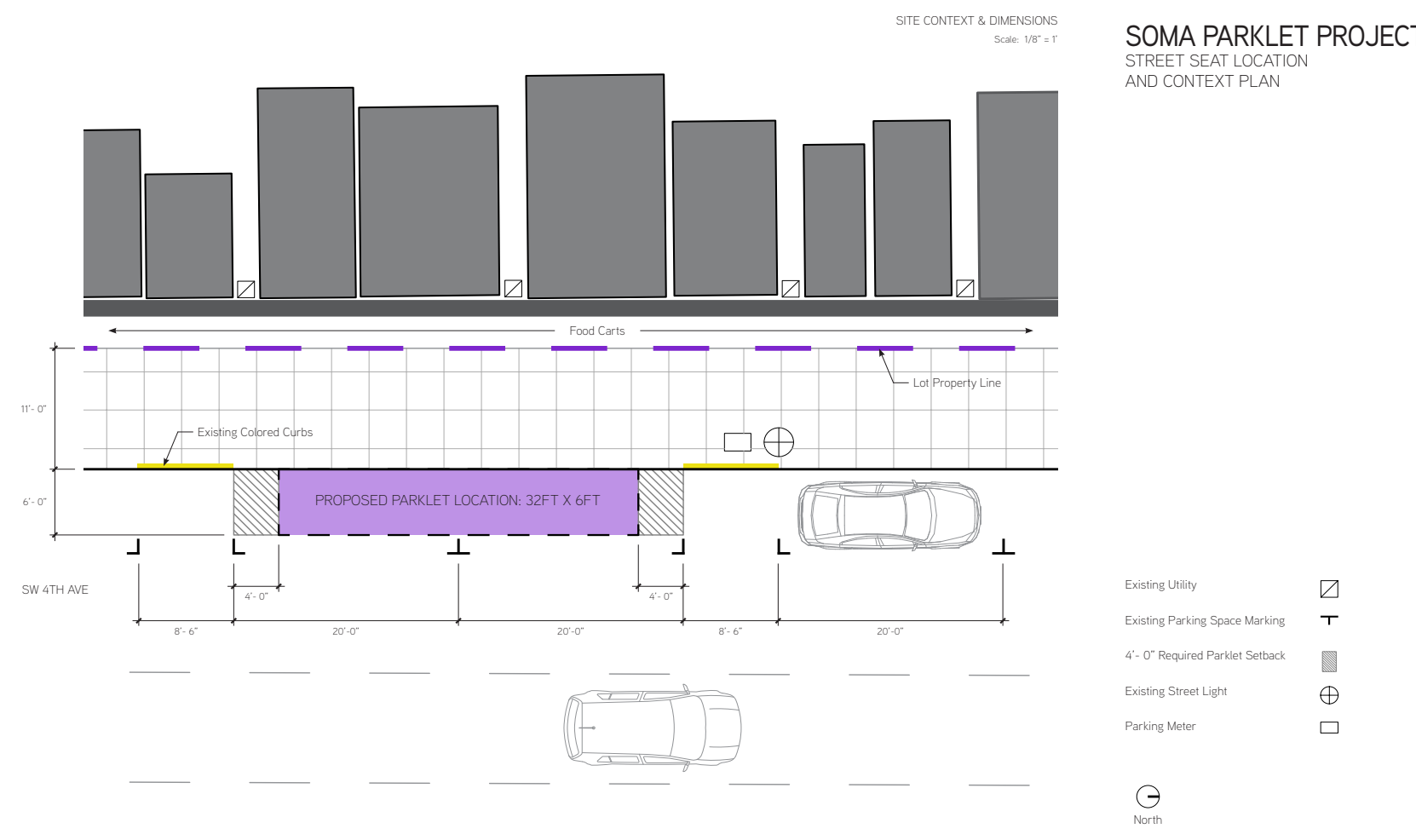

PARKLET PLAN

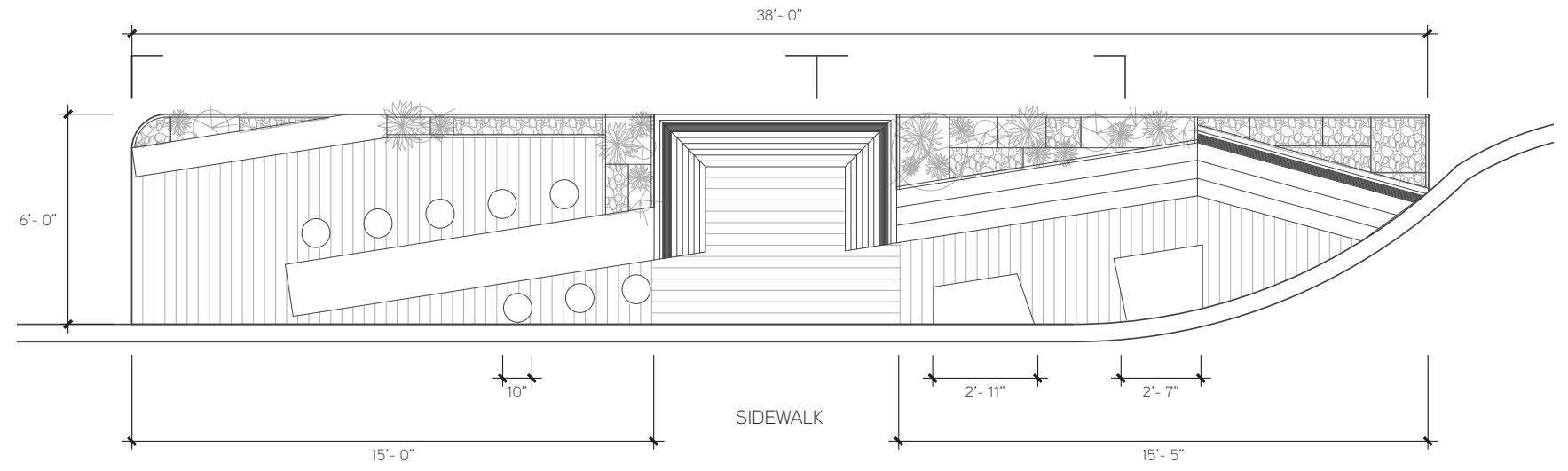

N.T.S. $€$ 



\title{
Permit Drawings
}

\author{
PARKLET PLAN
}

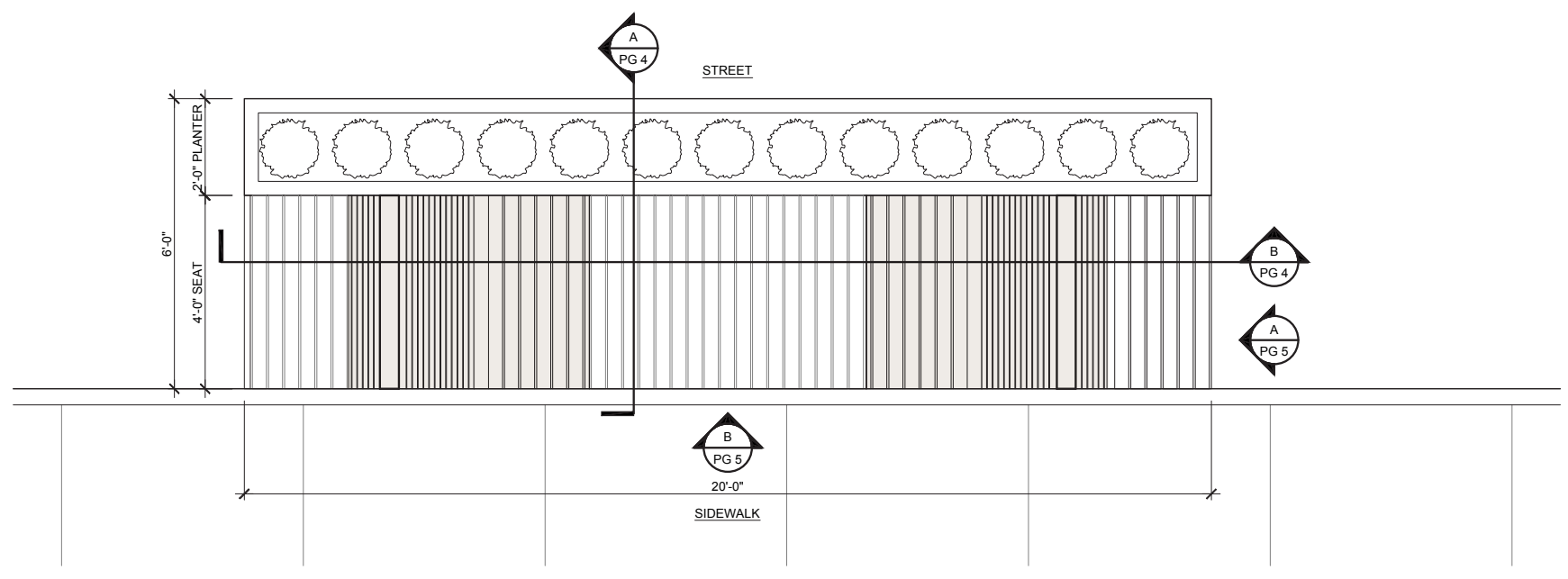

Floor Plan

Scale: $1 / 2^{\prime \prime}=1^{\prime}-0^{\prime \prime}$

A Dialogue

2014 Portland Street Seat Competition

\section{PARKLET ELEVATIONS}

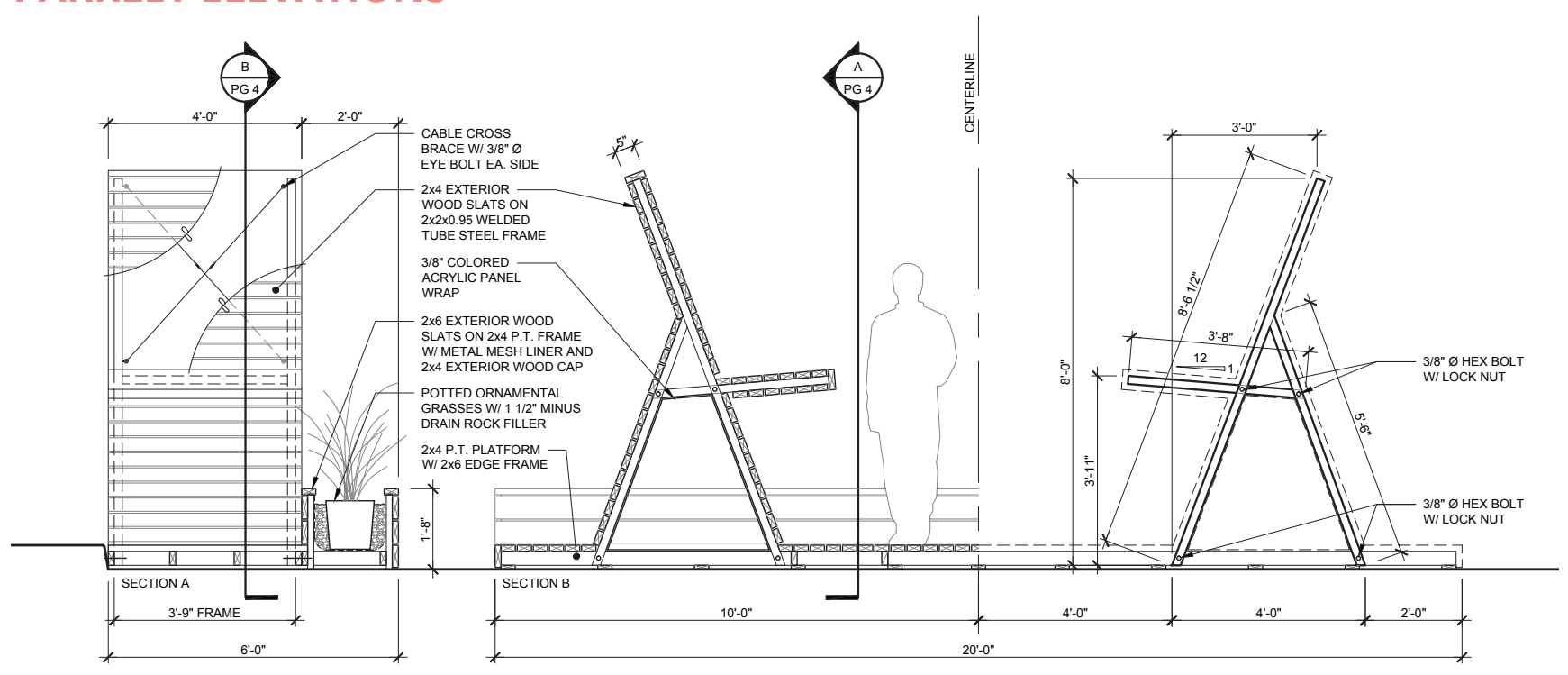

Sections

Scale: $1 / 2^{\prime \prime}=1^{\prime}-0^{\prime \prime}$ 


\section{Public Street Seat: Log Dam, Tin Shed}

THE STORY: “Log Dam” was one of two winning designs for the American Institute of Architects' Portland Center for Architecture's PARK(ing) Day design / build competition. After living in front of the Center for Architecture for several months, the seat moved to Alberta street and installed as a public parklet.

\section{ABOUT ME}

Location: 3023 NE Alberta St.

Date Opened: September 20, 2014

\section{Cost of Construction: $\$ 5,000$}

Permitting Cost: $\$ 600 /$ initial permit. $\$ 250 /$ permit renewal. No additional charges for this public street seat.

\section{Number of Seats: Up to 8}

Designed By: Scott Edwards Architecture

Built By: Scott Edwards Architecture and Ed Valik of I Build PDX

\section{LESSONS LEARNED}

- Designing a Structure to Move The dissasembled seats had to be moved from the Architect's Fiirm at SE Burnside and 26th across the river to SW 11 th and Glisan. To accomidate this move, and the move soon thereafter to Alberta St, the designers planned on a metal structure that could be disassembled. .

- An Internal Office Design Charette Spurred Great Concepts An internal competition at Scott Edwards Architecture chose this design for its conceptual clarity- street seat be literal seats- strucutre for people to play on and interact with where before there was only a parking space.

- Maintenance by Resturants and Alberta Main Street Works Although formally public, this project remains clean and well maintained because Vita Cafe is responsible for it.

\section{MATERIALS USED}

Glulam Beams form the benches

Cedar Decking- bright cedar slat clads the planters to add texture and detail

Feather Grass- Mexican feather grasses fill the planters, creating a "log dam" appearance

Crushed Granite acts as groundcover between the planters and the decking
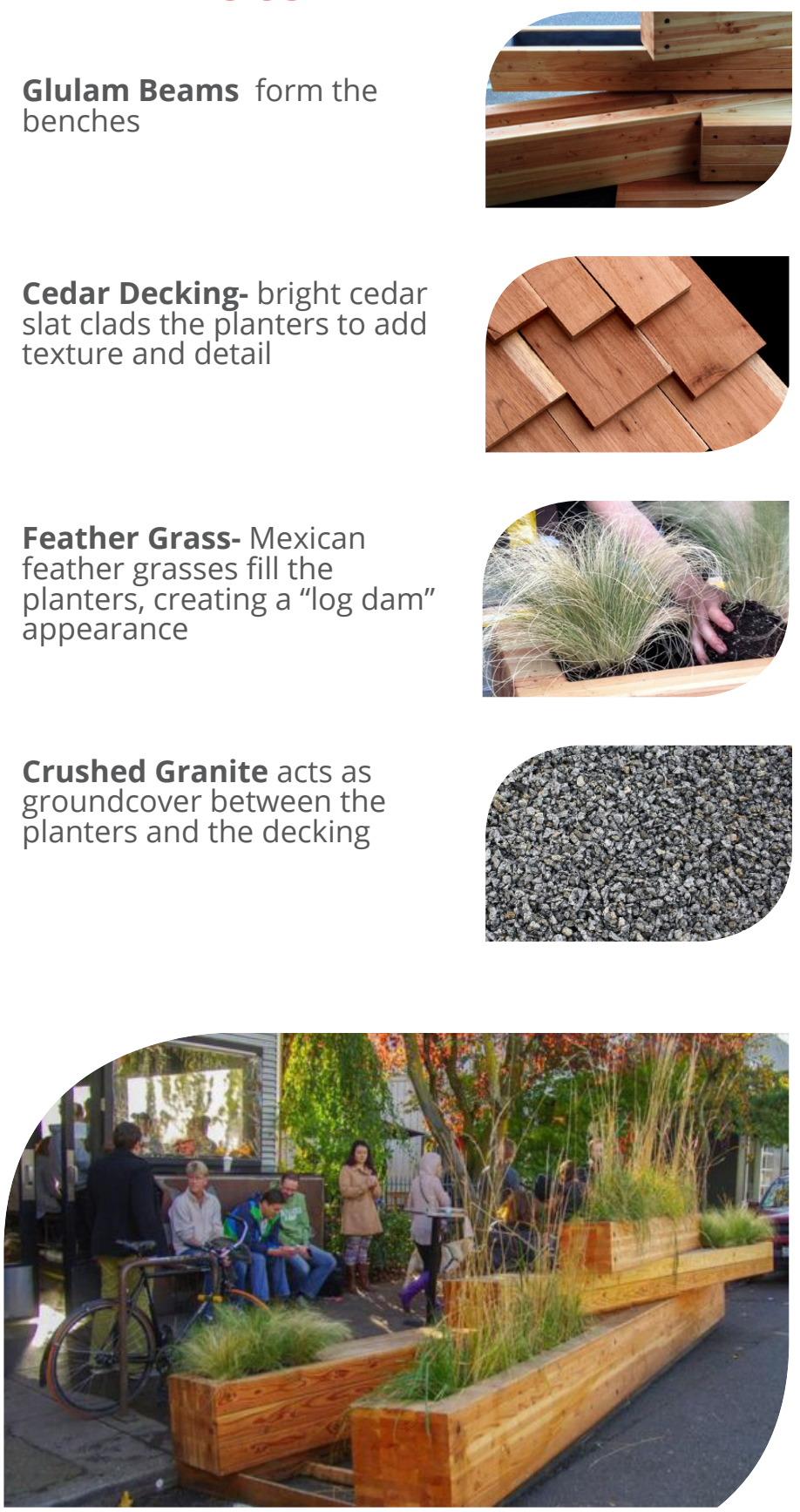

Photo Credits: Hennebery Eddy Architects 


\section{Permit Drawings}

\section{PARKLET PLAN}

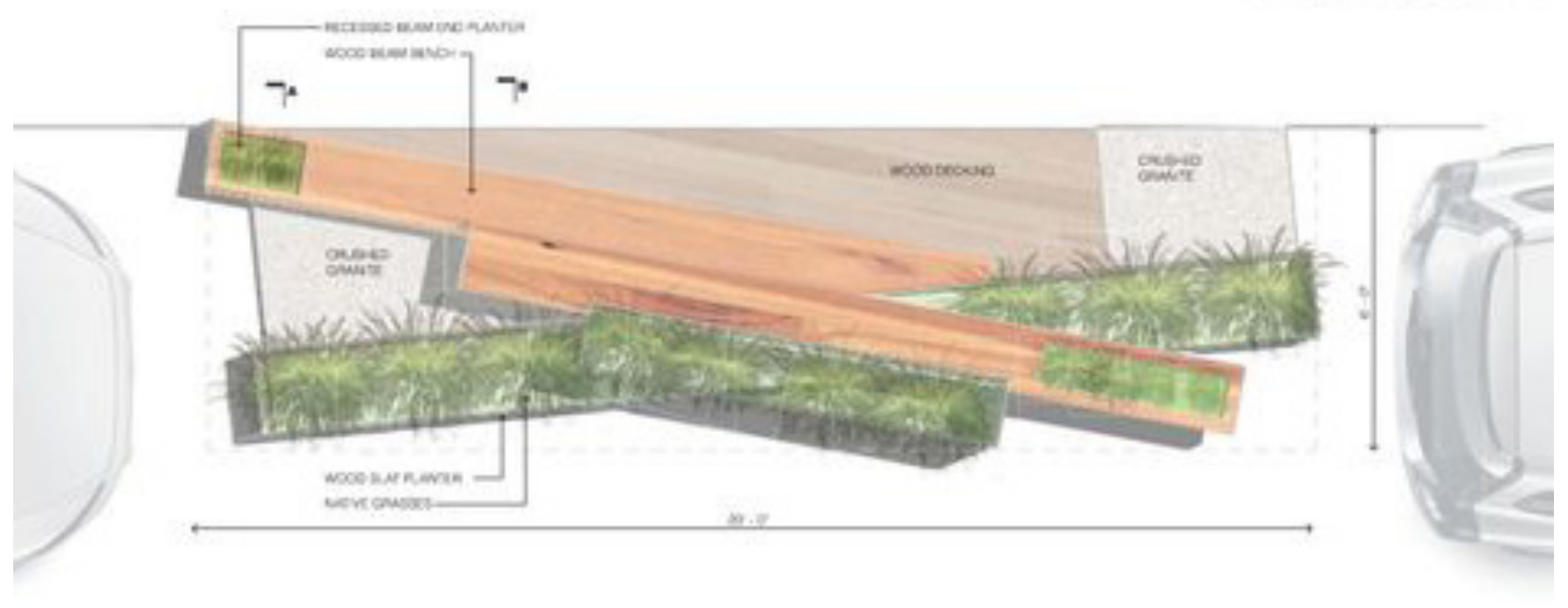

\section{PARKLET ELEVATIONS}

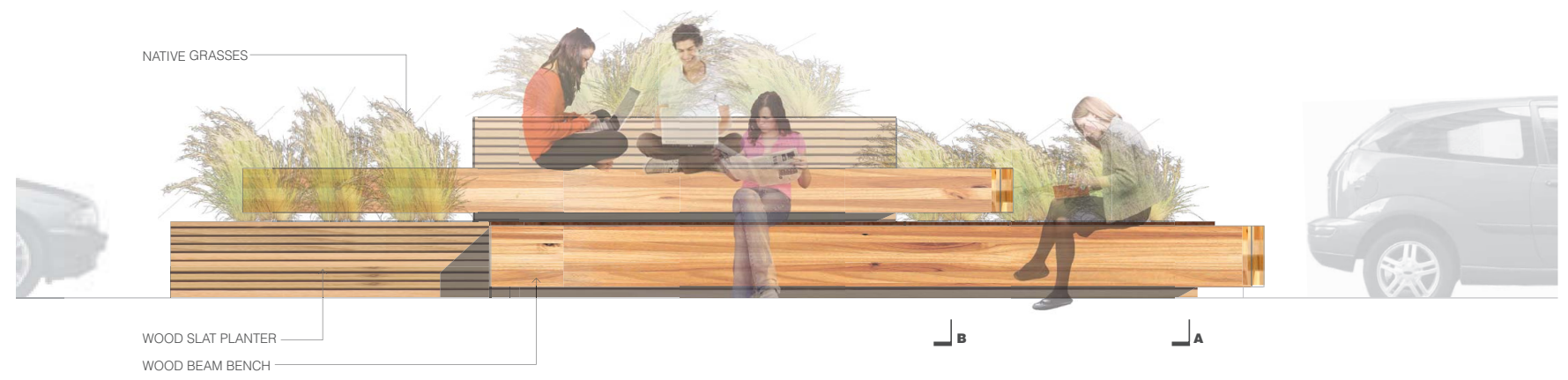

SIDEWALK ELEVATION

LOC DAM 


\section{Permit Drawings}

\section{SITE CONTEXT AND DIMENSIONS}

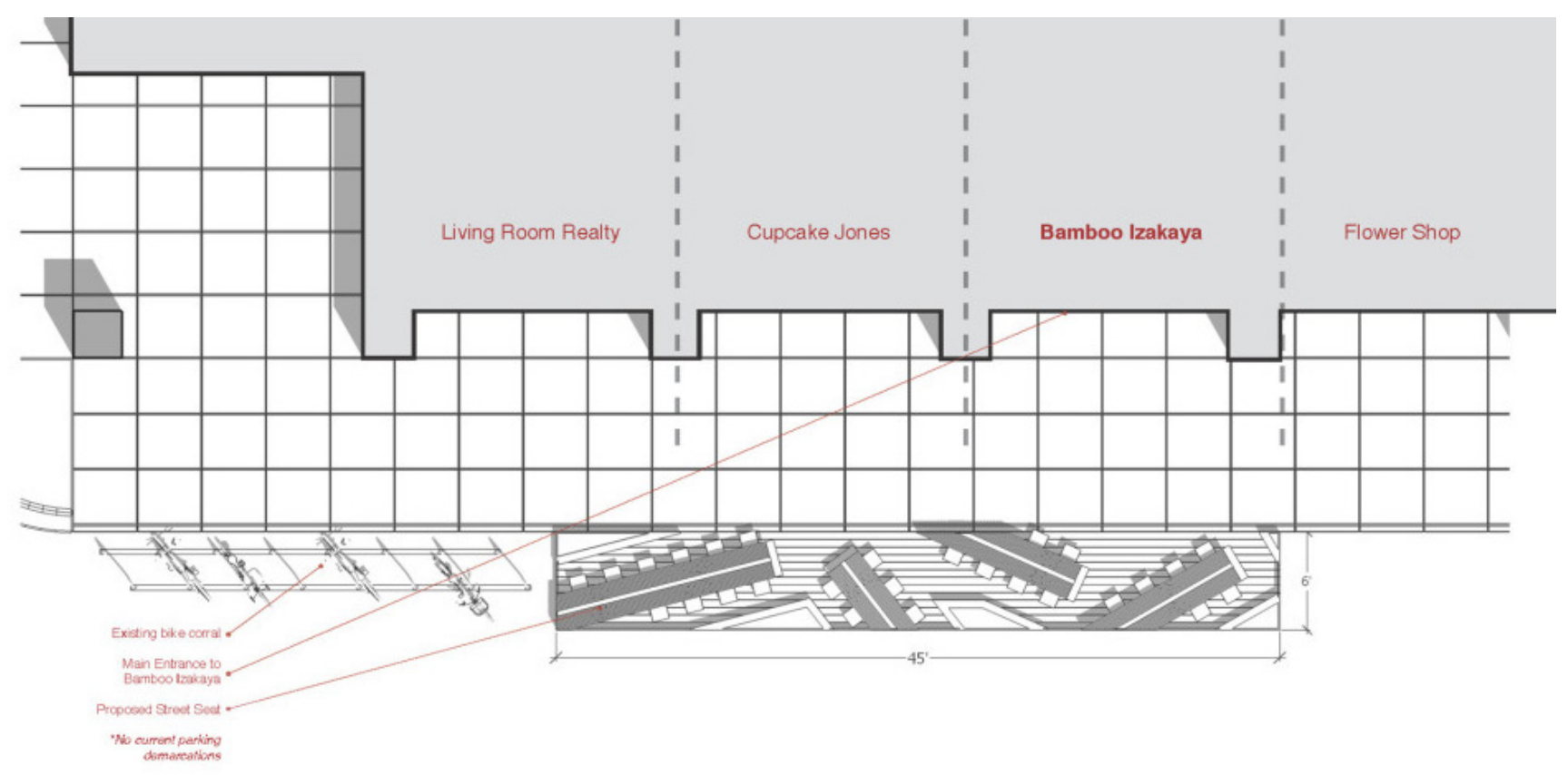

\section{PARKLET PLAN}

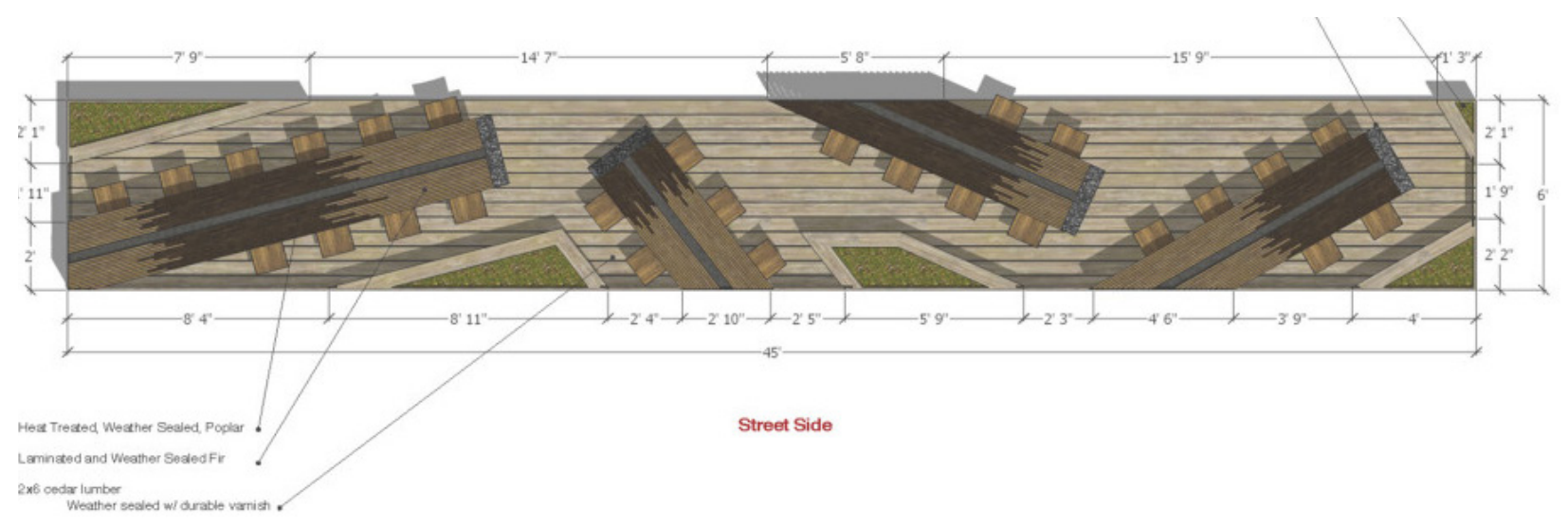

PARKLET ELEVATION

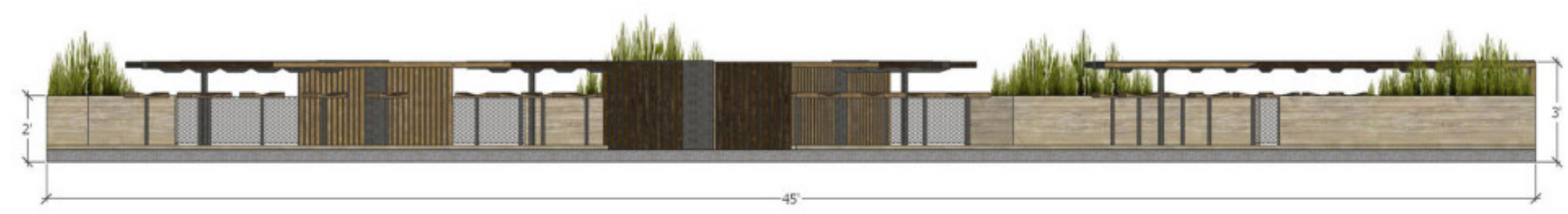

